\title{
EPSL
}

Earth and Planetary Science Letters 128 (1994) 513-526

\section{Magnetostratigraphic dating of the middle Miocene climate change in the continental deposits of the Aragonian type area in the Calatayud-Teruel basin (Central Spain)}

\author{
W. Krijgsman ${ }^{\text {a }}$, C.G. Langereis ${ }^{\text {a }}$, R. Daams ${ }^{\text {b }}$, A.J. van der Meulen ${ }^{c}$ \\ a Paleomagnetic Laboratory, Fort Hoofddijk, Budapestlaan 17, 3584 CD Utrecht, The Netherlands \\ ${ }^{\mathrm{b}}$ Departimento Paleontología e Institute de Geología Económica (UCM-CSIC), Faculty CC Geológicas, 28040 Madrid, Spain \\ ' Department of Geology, Institute of Earth Sciences, Budapestlaan 4, 3584 CD Utrecht, The Netherlands
}

Received 2 May 1994; accepted after revision 27 September 1994

\begin{abstract}
The exceptionally dense mammalian faunal record of the Aragonian type area in Central Spain shows that an important climate change towards a cooler and more humid climate is recorded during the Neogene Mammal Zone MN 5 [1]. The magnetostratigraphic results from mammal-bearing middle Miocene continental sections in the Aragonian type area indicate that the onset of this climate change, at the MN 4/MN 5 boundary, occurs in the reversed chron $\mathrm{C} 5 \mathrm{ACr}$ and has an age of $14.1 \mathrm{Ma}$, according to the geomagnetic polarity timescale (GPTS) of Cande and Kent [2]. This age is consistent with the age estimate of 14.1-14.05 Ma for the main increase in $\delta^{18} \mathrm{O}$ in the marine record [3]. These independent observations of time-equivalent cooling in both continental and marine records confirm and accurately date a global cooling event in the middle Miocene.

The age of $14.1 \mathrm{Ma}$ for the $\mathrm{MN} 4 / \mathrm{MN} 5$ boundary is significantly younger than previously recorded in continental timescales [4,5]. This results in a longer duration, by approximately $3 \mathrm{Myr}$, of the $\mathrm{MN} 4$ zone, which is consistent with the many important faunal changes occurring in MN 4. Furthermore, the MN 5/MN 6 boundary occurs in chron C5ACn (13.8-13.9 Ma) and the MN 6/MN 7-8 boundary in the interval C5Ar.1n-C5Ar.3r (12.7-13.0 Ma).
\end{abstract}

\section{Introduction}

The Aragonian land mammal stage was defined at the International Symposium of Mammalian Stratigraphy of the European Tertiary (Munich 1975) between the first appearances (FA) of the equids Anchitherium and Hipparion in Europe [6]. Later, the lower (Ramblian/ Aragonian) boundary was moved upward to the FA of Democricetodon, the first modern cricitid in central and western Europe [7]. The Aragonian stage comprises the Neogene Mammal Zones MN
$4,5,6,7$ and 8 in the nomenclature of Mein $[8,9]$ and De Bruijn et al. [10]. In the type area of the Aragonian, a local zonation has been made in Zones B to G3 [1,11]. Two new zones are recognised here: Zone $\mathrm{Dc}$ is characterised by Megacricetodon collongensis, Fahlbuschia koenigswaldi and Pseudofahlbuschia (Cricetidae, hamsters), which are common components associated with Pseudodryomys simpliciders and $P$. ibericus (Gliridae, dormice); zone Dd contains mainly the same species as Dc, although Peridyromys rex is also present. Chronostratigraphic control of 
Aragonian sediments is only based on indirect correlations of MN zones with marine biostratigraphy. In the Tertiary basins of central Spain there are no opportunities for correlating the continental successions to the marine scale because of the scarcity of marine intercalations. Radiometric calibration to the absolute timescale is impossible owing to the absence of intercalated rocks of volcanic origin. Because are no reliable age determinations, controversies exist about almost all the biostratigraphic zones and boundaries [5].

The oldest Aragonian faunas are placed in Neogene Mammal Zone MN 4. The MN 3/MN 4 boundary-by definition the Ramblian/Aragonian boundary - is not directly dated, and its age is based on correlation with marine planktonic zones. In the recent literature, this boundary, which is based on an ambiguous correlation with nannofossil zones in Portugal, is set at 17.8 $\mathrm{Ma}[5]$ or at $18.5 \mathrm{Ma}[1]$.

The position of the upper (Aragonian/Vallesian) boundary has been a subject of debate because the FA of Hipparion seems to be a clear example of diachrony. Berggren et al. [4] placed this boundary at $12.5 \mathrm{Ma}$ based on radiometric dates on sites from Germany. Sen [12] has suggested that Hipparion appears in the Mediterranean at approximately $11.5 \mathrm{Ma}$, within chron C5R. The FA of Hipparion in the Siwaliks of Pakistan is magnetostratigraphically dated (in chron C5n) at $10 \mathrm{Ma}$ [13]. Finally, Steininger et al. [5] place the Aragonian/Vallesian boundary at $11.5 \mathrm{Ma}$.

The marine records clearly show that major paleoceanographic and paleoclimatic changes have occurred in the middle Miocene. These changes represent an important step towards near-modern oceanographic conditions. Foraminiferal assemblages established in the middle Miocene persisted through the late Neogene $[14,15]$. A change in the rate of ${ }^{87} \mathrm{Sr} /{ }^{86} \mathrm{Sr}$ increase is thought to have occurred at 14.8-14.6 $\mathrm{Ma}$ and was interpreted as the development of a permanent Antarctic ice cap [16]. Global increases in $\delta^{18} \mathrm{O}$ from 16.2 to $12 \mathrm{Ma}$ are considered to reflect major ice sheet growth on Antarctica [17-21]. Flower and Kennett [3] showed that the main increase in $\delta^{18} \mathrm{O}$ in the middle Miocene (event Mi3 [16]) occurred between 14.5 and 14.0 $\mathrm{Ma}$, with a major increase between 14.1 and 14.05 Ma. The dating of this event was based on magnetostratigraphic [22], biostratigraphic [23] and isotopic [20] data.

The middle Miocene climate change is well recorded in the marine record, but the effects of the climate change on the continental fauna record are poorly known. The scarcity of fossil localities and the rather scattered outcrops makes it difficult to study large-scale climatic changes on land. The Aragonian type area, however, shows abundant fossiliferous levels covering successive Neogene mammal zones (see Fig. 7). The dense mammalian faunal record of the Aragonian makes

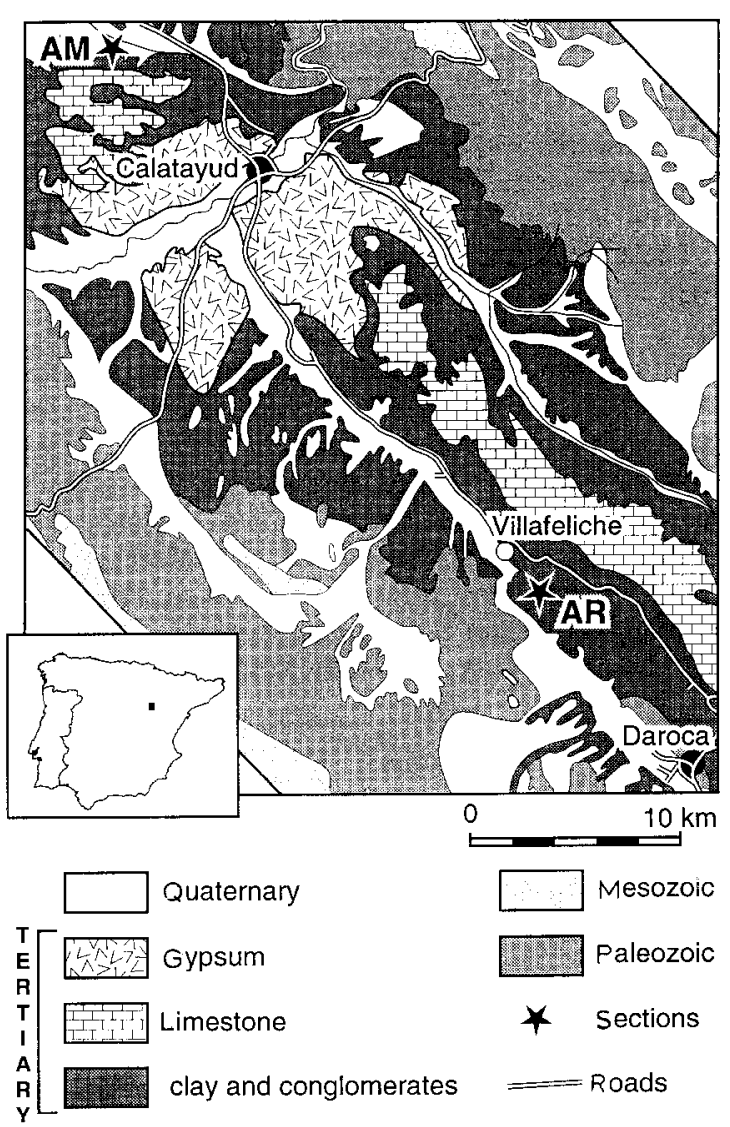

Fig. 1. Location of the Aragon ( $A R$ ) and Armantes ( $A M$ ) sections in the type area of the Aragonian in the CalatayudTeruel basin of central Spain (slightly modified after Dijks$\operatorname{man}[24]$ ). 
it possible to apply principal component analyses to the rodent assemblages from the Ramblian and Aragonian [1]. An important result was the recognition of a major cooling phase in the middle Aragonian during Zone $\mathrm{E}$, which is the correlative of Zone MN 5. According to Steininger et al. [5], MN 5 spans the interval from 17 to 16 $\mathrm{Ma}$, which suggests that the climate change to a colder state on land significantly pre-dates the changes in the marine record by several million years. Van der Meulen and Daams [1] bracketed the cooling event between 15 and $13 \mathrm{Ma}$, based on paleomagnetic data by Dijksman [24] and marine-continental tiepoints in Portugal. Age determinations, especially for the mammal zones, however, are still ambiguous [5].

The stratigraphic position of the middle Miocene (MN 5) climate change is accurately tied into the Aragonian type section. To make a direct correlation of the climate change to the GPTS we have sampled the Aragonian type section for magnetostratigraphic purposes. To obtain a reliable chronostratigraphic framework for the standard mammal zonations of the middle Miocene Aragonian stage we have also sampled a timeequivalent section near the village of Calatayud which we could extend to older levels. In this paper we present the magnetic polarity stratigraphy of the two sections in the Aragonian type area and their correlation to the geomagnetic polarity timescale (GPTS).

\section{Sections and sampling}

The Aragonian stage was defined in the $\mathrm{Ca}$ latayud-Teruel basin of Central Spain [25], in the Iberian range between the Western and Eastern Iberian Chains (Fig. 1). The sediments in the type area consist mainly of breccias, conglomerates, sands, silts, clays, lacustrine limestones and gypsum. Throughout the area, the reddish fluviatilelacustrine sediments are capped by a thick formation of alternating white-greyish marls and white limestones. This formation is thought to be partly of Vallesian age, because fossil localities found laterally contain Vallesian faunas [25]. The most favourable sediments for fossil accumulation were, in general, clays, silts and marls, in particular those with lignitic contents and/or concentrations of freshwater or terrestrial molluscs.

\subsection{The Aragon section}

The Aragon section is $170 \mathrm{~m}$ thick and comprises the partly overlapping Valdemoros (VA), Las Umbrias (LUM) and Las Planas (LP) sections [25]. The section is located approximately 1 $\mathrm{km}$ southeast of the village of Villafeliche (Fig. 1). The base of the section consists of red silts and clays containing red conglomerate (channel fills) and white limestone beds and it discordantly overlies the Cambrian basement. The number of limestone beds gradually increases higher up in the section while the reddish colour diminishes. The middle part of the section consists of whitish limestones and white-grey marls with limestone beds up to $3 \mathrm{~m}$ in thickness (Fig. 2). A second unit composed of red silty clays with some pebbly interbeds and white limestones overlies the white marl-limestone interval. The upper part of this unit consists of thick (up to $10 \mathrm{~m}$ ) red clay beds in which some limestone beds are intercalated (Fig. 2 ). These clays are in turn capped by a formation of white limestones.

In the Aragonian section, 143 sites were sampled at an average spacing of approximately 1.5 $\mathrm{m}$. At each site two paleomagnetic cores were drilled after first removing the weathered surface. We attempted to sample the section as long and continuously as possible to obtain the maximum number of polarity zones. Unfortunately, the uppermost part of the section was sampled in less detail because of fewer levels with suitable lithology.

\subsection{The Armantes section}

The Armantes section, named after the Sierra de Armantes, is located a few kilometres northwest of the village of Calatayud (Fig. 1). This section is $280 \mathrm{~m}$ thick and was sampled along the northern slope of the mountains (Fig. 1). The base of the section (Armantes A [26], or Ribota [24]) consists of a unit of red silts and sands, while the top is formed by a unit of $10 \mathrm{~m}$ of white 
limestones (44-54 $\mathrm{m}$ in Fig. 3). The major part of the Armantes section consists of a rhythmic alternation of red clays and pink-white limestones

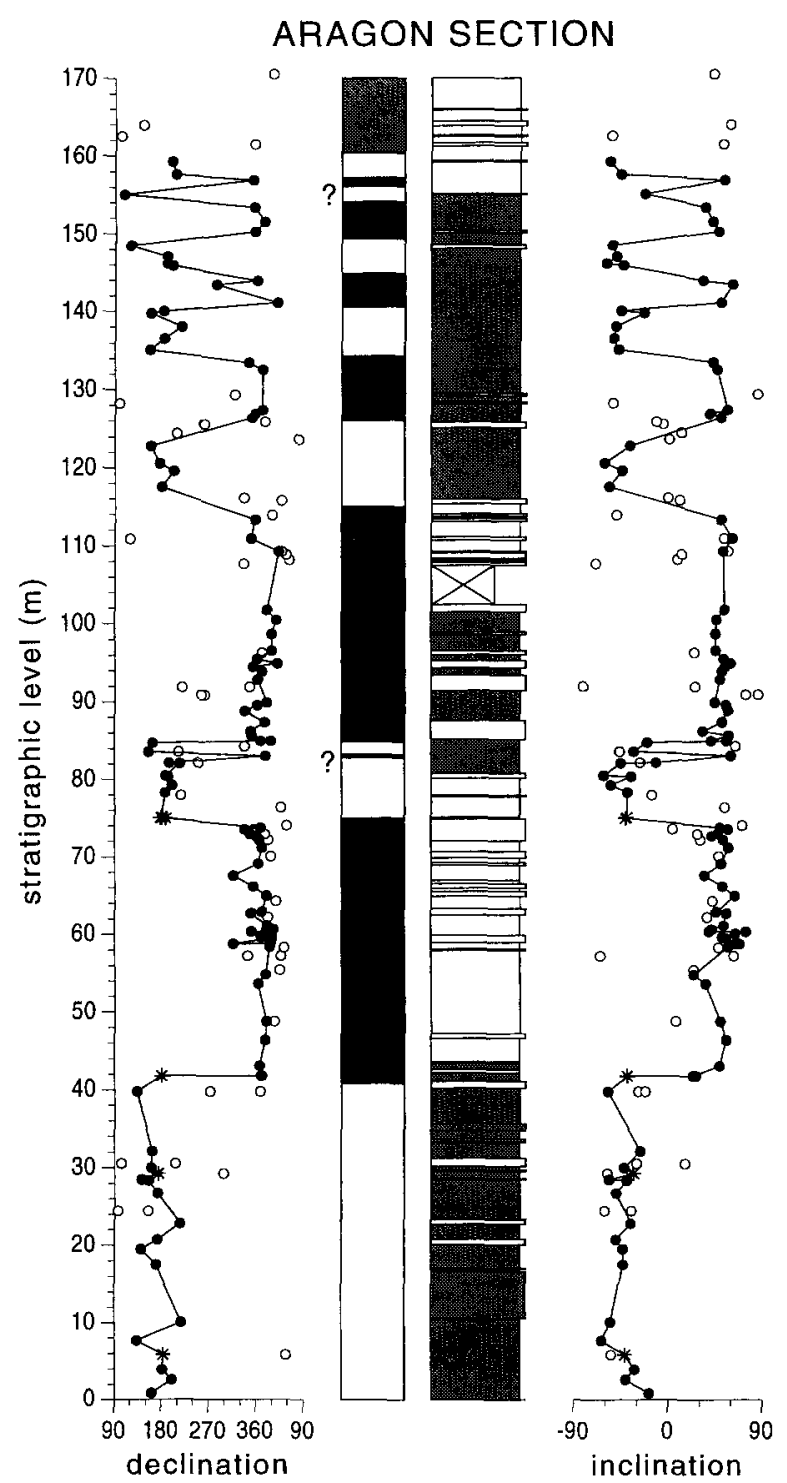

Fig. 2. Magnetostratigraphy and lithology of the Aragon section. $\bullet$ Reliable directions; $O=$ low-intensity samples which are difficult to interpret; $*=$ directions obtained by applying the great circle method [28]. In the polarity column, black/white denotes normal/reversed polarity zones; shaded interval denotes a zone of uncertain polarity; question marks denote polarity intervals based on a single level. The lithology column displays variations of red silts and conglomerates (shaded) and greyish-white marls and limestones (white).

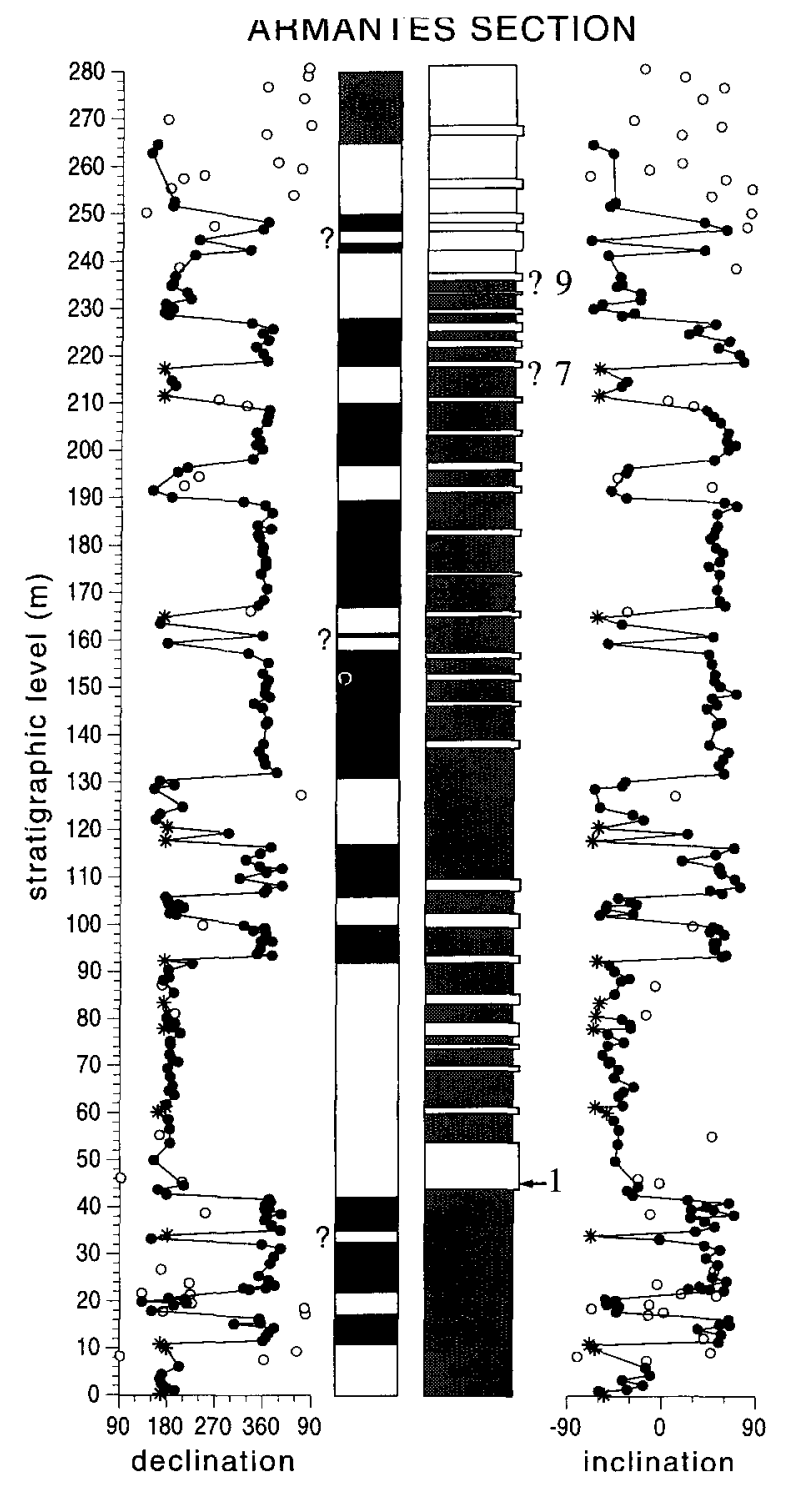

Fig. 3. Magnetostratigraphy and lithology of the Armantes section. See also caption to Fig. 2. Arrow indicates position of fossil locality Armantes 1; question marks denote uncertain positions of fossil localities Armantes 7 and 9, in the upper part of the section [24].

(Fig. 3). This alternation is remarkably continuous and throughout the whole section limestone beds are observed, which is especially evident in the more weathered parts of the section. Between the thick limestone beds, smaller beds are observed at irregular distances and at several levels 


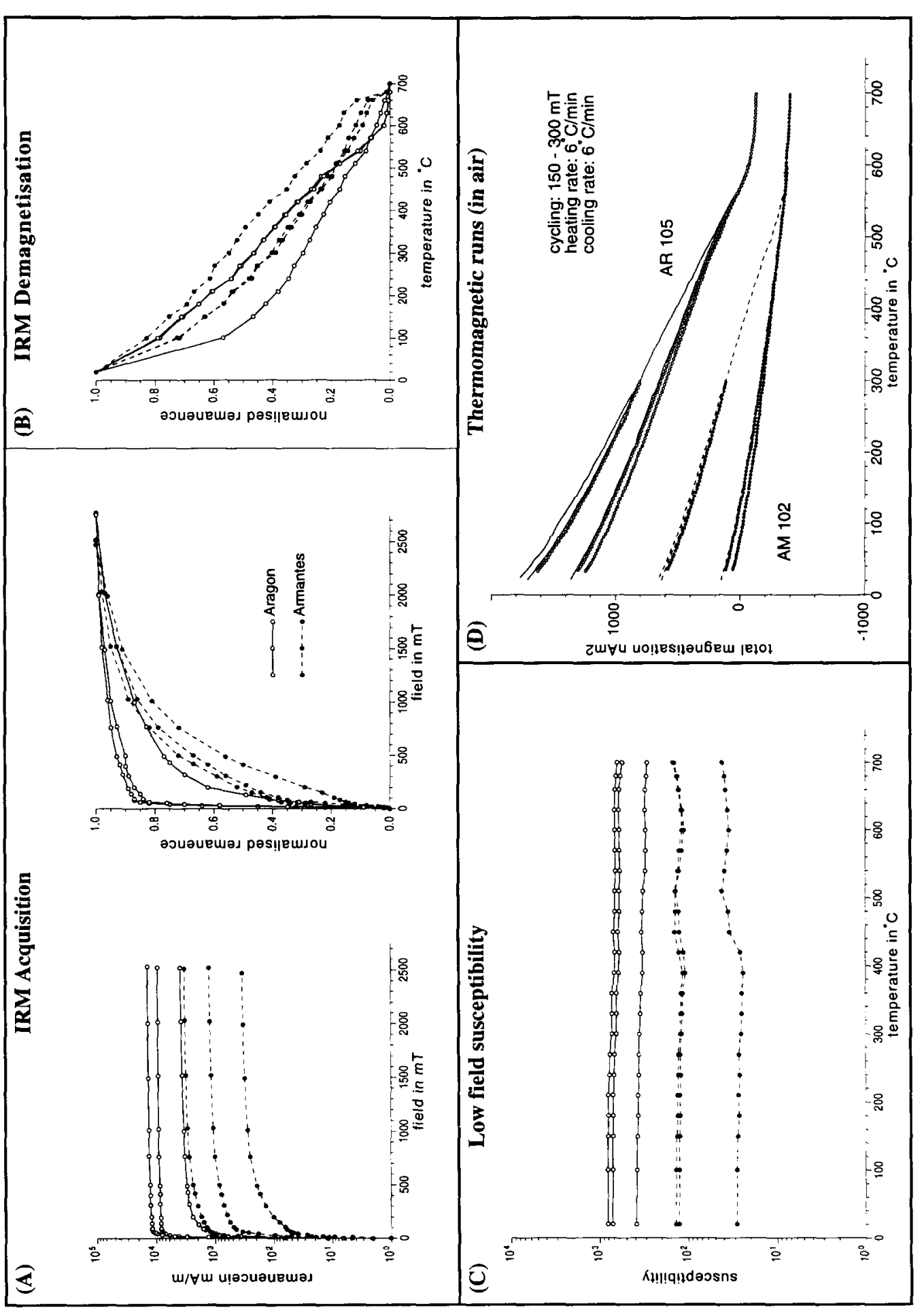

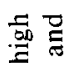

के

范

莺

䙵

$\frac{\pi}{5}$

E

氖

$\stackrel{\square}{\Xi}$

E

0

\%

$\sum \dot{\vec{\sigma}}$

I.

氙焉

氞总

西

$\stackrel{\Xi}{\stackrel{\Xi}{E}}$

등

들

证

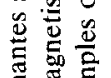

है

号 画

它焉

5 .

言

空

合部

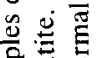

氖

象.

5

产论

䓌总

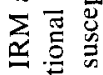

훙ㅎㅁ

를

武品云

这常.

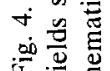




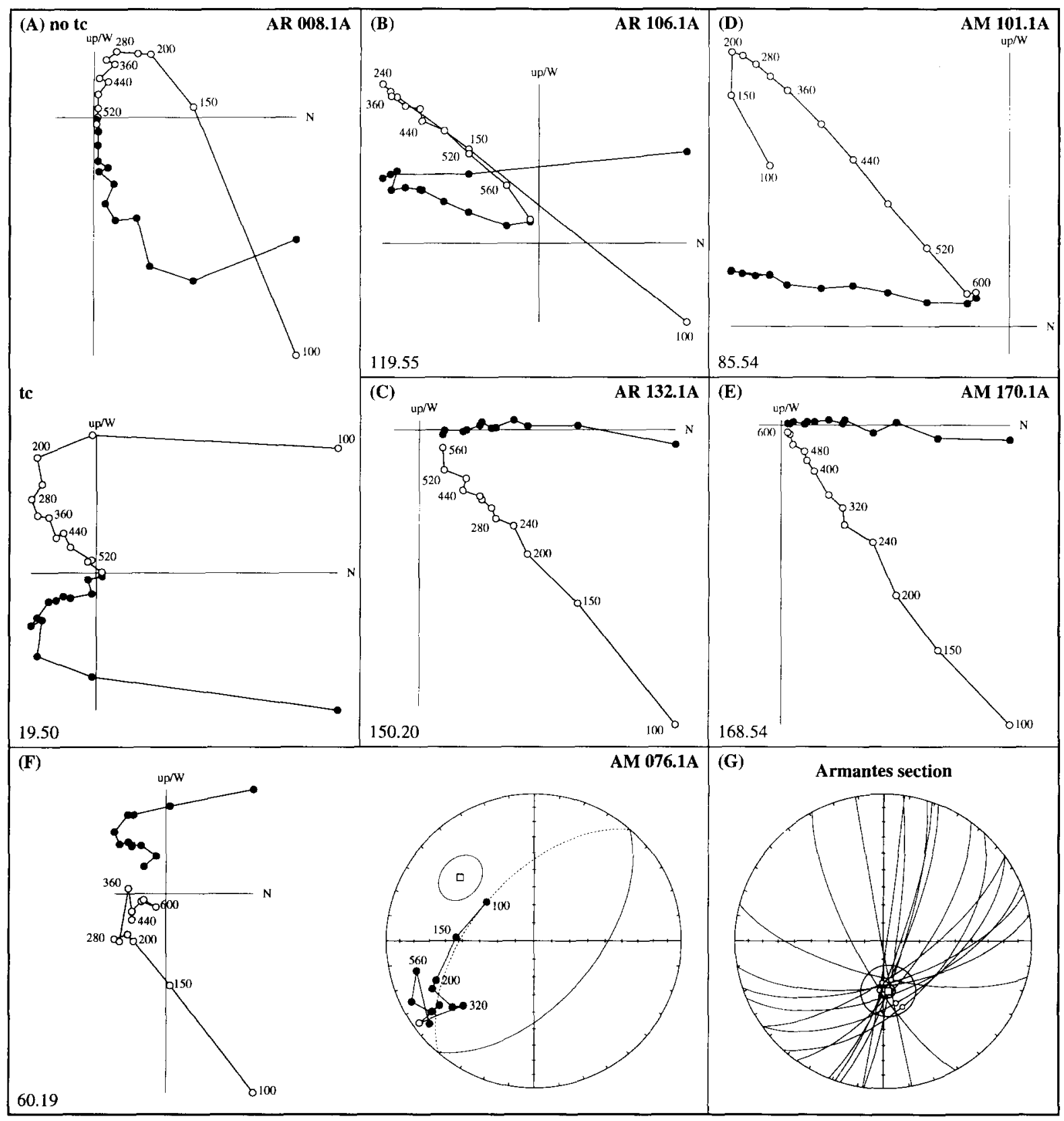

Fig. 5. Thermal demagnetisation diagrams for samples from the Aragon and Armantes section. $\bullet / O=$ projection on the horizontal/vertical plane; values are temperature steps $\left({ }^{\circ} \mathrm{C}\right.$ ); stratigraphic levels are in the lower left-hand corner. (A) Example from the steeply dipping lower part of the section, displaying at low temperatures a present-day field component before tilt correction (no $t c$ ) and at high temperatures a characteristic primary component after tilt correction ( $t c$ ). (F) Example showing no clear linear decay to the origin; the great circle in the equal-area projection suggests that a reversed ChRM is not fully resolved. $\square=$ the normal to the plane with its error. (G) The intersections of all great circle planes as estimate of the primary directions. 
thin conglomerates are intercalated. The regular cyclicity observed in the section suggests that a relationship exists with climatic changes induced by astronomical cycles of Earth's orbit. The upper part of the section (Armantes B [26], or Calatayud [24]) is overlain by a thick succession of white limestones and dolomites with some rare intercalations of reddish sediment (Fig. 3).

The Armantes 1 fossil locality is located directly in the sampled section. Two other localities, Armantes 7 and 9, are located respectively 3 and $1 \mathrm{~km}$ southwest of the sampled section. Dijksman [24] tentatively correlated these to an approximate position at the top of the Armantes section (Fig. 3).

The paleomagnetic samples were taken at an average spacing of approximately $1-1.5 \mathrm{~m}$. At each site we drilled two standard paleomagnetic cores. The section could not be sampled at evenly spaced intervals because the red silts were often impossible to drill. We succeeded, however, in drilling several levels between all the thick limestone beds.

\section{Rock magnetic properties}

We performed some rock magnetic experiments on selected samples of both the Aragon and Armantes section to identify the carriers of the NRM components. These rock magnetic experiments include acquisition of an isothermal remanent magnetisation (IRM) on a PM 4 pulse magnetiser (H. Böhnel) and subsequent thermal demagnetisation. Susceptibilities were measured after each temperature step on a Kappabridge KLY-2. Finally, some thermomagnetic runs were recorded with a modified horizontal translation Curie balance making use of a cycling field [27].

In the samples of both the Aragon and Armantes section the acquisition of the IRM shows an initial steep rise as far as $100 / 200 \mathrm{mT}$, suggesting the presence of a low-coercivity mineral like magnetite or maghemite; after this point the IRM increases gradually (Fig. 4A). Saturation is generally not reached in the highest fields $(2500$ $\mathrm{mT}$ ), which indicates the additional presence of a high-coercivity mineral like goethite or hematite.
The unblocking temperatures after thermal demagnetisation of the IRM (Fig. 4B) support the presence of magnetite and, especially for the Armantes section, hematite as the dominant magnetic carriers. The rapid decay at low temperatures in some samples suggests the occasional presence of goethite.

The initial susceptibility shows no important changes in the samples of the Aragon section when heated to $700^{\circ} \mathrm{C}$ (Fig. $4 \mathrm{C}$ ), indicating that no additional magnetic minerals are produced during heating of the samples. Some samples of the Armantes section show a small increase in susceptibility at temperatures higher than $400^{\circ} \mathrm{C}$ (Fig. 4C). The thermomagnetic runs on the Curie balance also imply that no additional magnetic material is produced during heating to $700^{\circ} \mathrm{C}$ (Fig. 4D). The sample of the Aragon section indicates the presence of magnetite, because the results reveal a Curie point of $580^{\circ} \mathrm{C}$. The rock magnetic experiments suggest that the main carriers of the magnetisation are hematite and magnetite but that also small amounts of goethite may be present.

\section{Paleomagnetic results: Magnetostratigraphy}

The natural remanent magnetisation (NRM) was measured on a $2 \mathrm{G}$ Enterprises cryogenic magnetometer. The total NRM intensities are generally high, ranging from 0.1 to $10 \mathrm{~mA} / \mathrm{m}$, and are strongly related to the lithology. Generally, the reddish silts and clays show much higher intensities than the white limesones and marls. The low-field susceptibility ranges from 50 to $1500 \times 10^{-6}$ SI. At least one specimen from each sample site was progressively demagnetised using $30^{\circ} \mathrm{C}$ temperature steps.

\subsection{Aragon section}

In the Aragon section, thermal demagnetisation of the samples reveals that the total NRM is generally composed of three components. A small viscous and randomly oriented component disappears at temperatures of $100^{\circ} \mathrm{C}$. A relatively large secondary component is generally removed at 


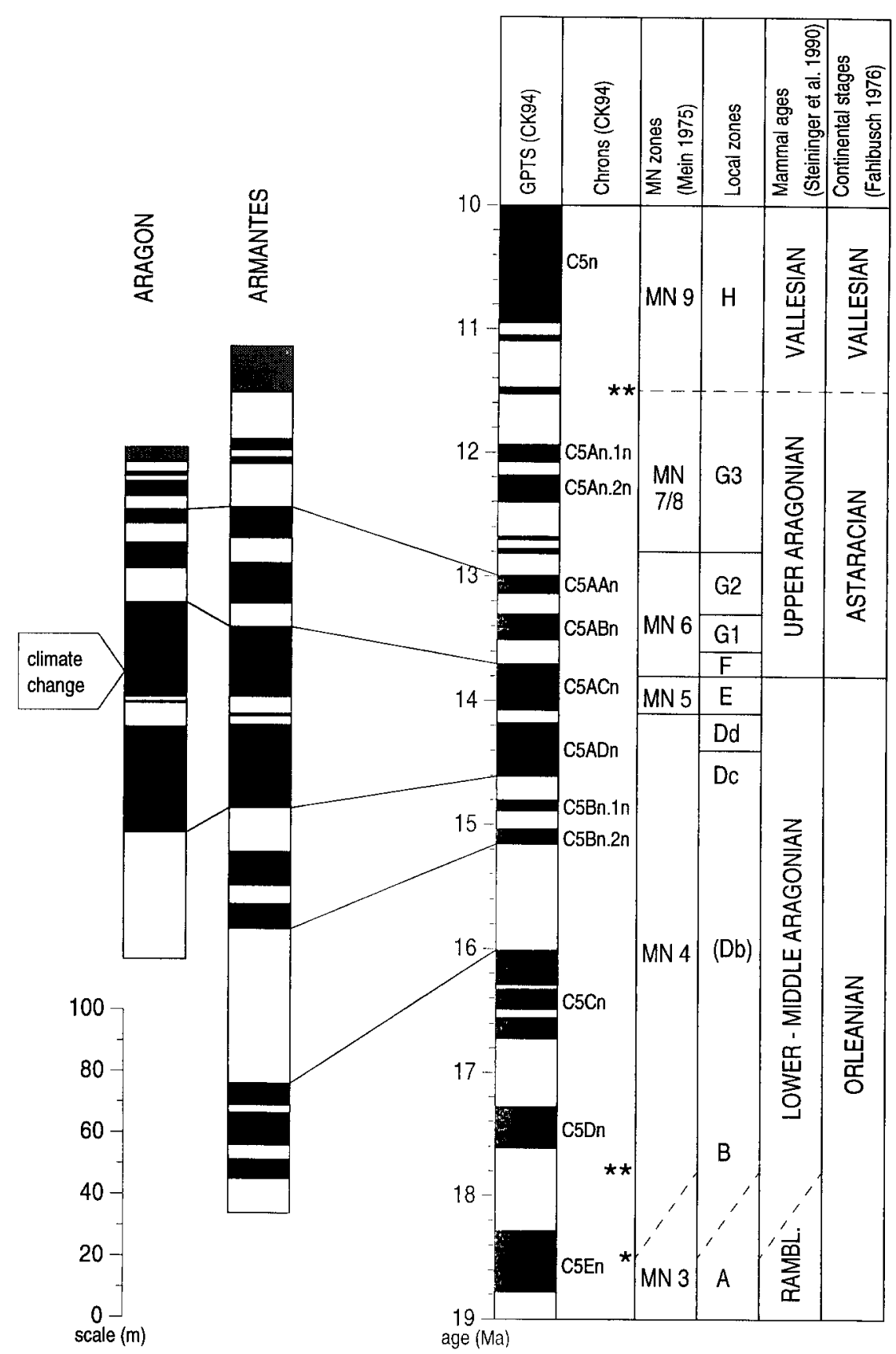

Fig. 6. Correlation of the Armantes and Aragon sections to the GPTS of Cande and Kent [2]. Lines connect corresponding reversal boundaries. The polarity zones of the Aragon and Armantes sections are in metres. Arrow on the left-hand side indicates the stratigraphic position of the climate change as observed in the biostratigraphic record in the Aragon section (see also Fig. 7). Right-hand columns display mammalian zones and stages. Ages of the zone and stage boundaries (solid lines) are from this study (see Table 1). Asterisks (* [1]; ** [5]) represent ages from the literature for zone boundaries (dashed lines). 
temperatures of $240^{\circ} \mathrm{C}$ (Fig. 5A). It has an approximately present-day field direction before bedding tilt correction and is therefore of recent origin and most probably caused by weathering of the sediments. A characteristic remanent magnetisation (ChRM) is generally removed at temperatures below $580^{\circ} \mathrm{C}$. The demagnetisation diagrams are generally of good quality and in most cases the characteristic directions can be reliably determined (Figs. 5B and C). Only in the white limestones do several levels show less reliable results because of a very weak magnetic signal, although the polarity $(\mathrm{N} / \mathrm{R})$ is usually clear (Fig. 2).

Some samples do not show a simple linear decay to the origin, even if the polarity is clear. It is assumed that the primary component is partly overprinted by a secondary component caused by overlapping unblocking temperature spectra. In these cases, a best-fit plane is calculated through the datapoints using the method of McFadden and McElhinny [28].

The ChRM directions and polarity zones (Fig. 2) show that fifteen polarity intervals have been recorded. Unfortunately the uppermost polarity intervals are only determined by a few samples and must therefore be considered as less reliable. The most conspicuous characteristics of the Aragon polarity sequence are the two long normal intervals in the middle part of the section which are separated by a relatively short reversed interval. Within this reversed interval one level is observed which shows a normal polarity.

\subsection{Armantes section}

Like in the Aragon section the thermal demagnetisation diagrams of the Armantes section reveal a stable and well-defined ChRM component after removing a secondary present-day field component at $240^{\circ} \mathrm{C}$. Susceptibilities and ChRM intensities are lower than in the Aragon section. Polarities are evident and characteristic directions can often be reliably determined (Figs. 5D and E). Generally, the total remanence is not entirely removed at temperatures of $600^{\circ} \mathrm{C}$ and hematite probably contributes to the characteristic magnetisation. Best-fit planes [28] for the sam- ples without a clear linear decay to the origin (Fig. 5F) were used to estimate the characteristic directions (Fig. 5G). Some samples in the Armantes section show demagnetisation diagrams that are impossible to interpret or, like the limestones in the upper part of the section, have such low intensities that characteristic directions cannot accurately be determined (Fig. 3).

Twenty-five polarity intervals.. have been recorded in the Armantes section. The uppermost polarity intervals are represented by only a few samples and are hence less reliable. In the middle part of the section a single normal polarity level is observed in a reversed interval. In this case, it is not clear whether the sample representing this interval is totally overprinted by a normally directed weathering component or whether it represents a very small normal interval. It does occur in the same reversed interval as the single normal level of the Aragon section, although the relative positions are different.

\section{Correlation to the GPTS}

Correlation of the Aragonian sections to the GPTS has been made by reference to the most recent published version (CK94 [2]). Because the polarity sequence of the Armantes section contains 25 polarity intervals and the regular cyclic sedimentary patterns suggest a fairly constant sedimentation rate this section is very suitable for correlation to the GPTS. Clearly, only one unambiguous correlation can be made (Fig. 6); all other correlations result in sudden and unlikely changes in sedimentation rate. It shows that the Armantes section covers a continuous time interval of almost 5 Myr. The base of the section corresponds to chron $\mathrm{C} 5 \mathrm{Cr}$ and has an age of $17.0 \mathrm{Ma}$; the top of the section is estimated at 12.4 Ma according to CK94. Furthermore, it appears that every polarity zone is recorded and that no significant hiatuses exist. This makes the Armantes section a unique and important continental reference section for the middle Miocene.

Although the different lithologies of the Aragon section suggest changing sedimentation rates, the correlation to the Armantes section 
and hence to the SPTS is unequivocal (Fig. 6). The Aragon section is biostratigraphically younger than the Armantes 1 fossil locality, whereas the top of the Aragon section is biostratigraphically the time equivalent of the top of the Armantes section. This results in only one possible correla-

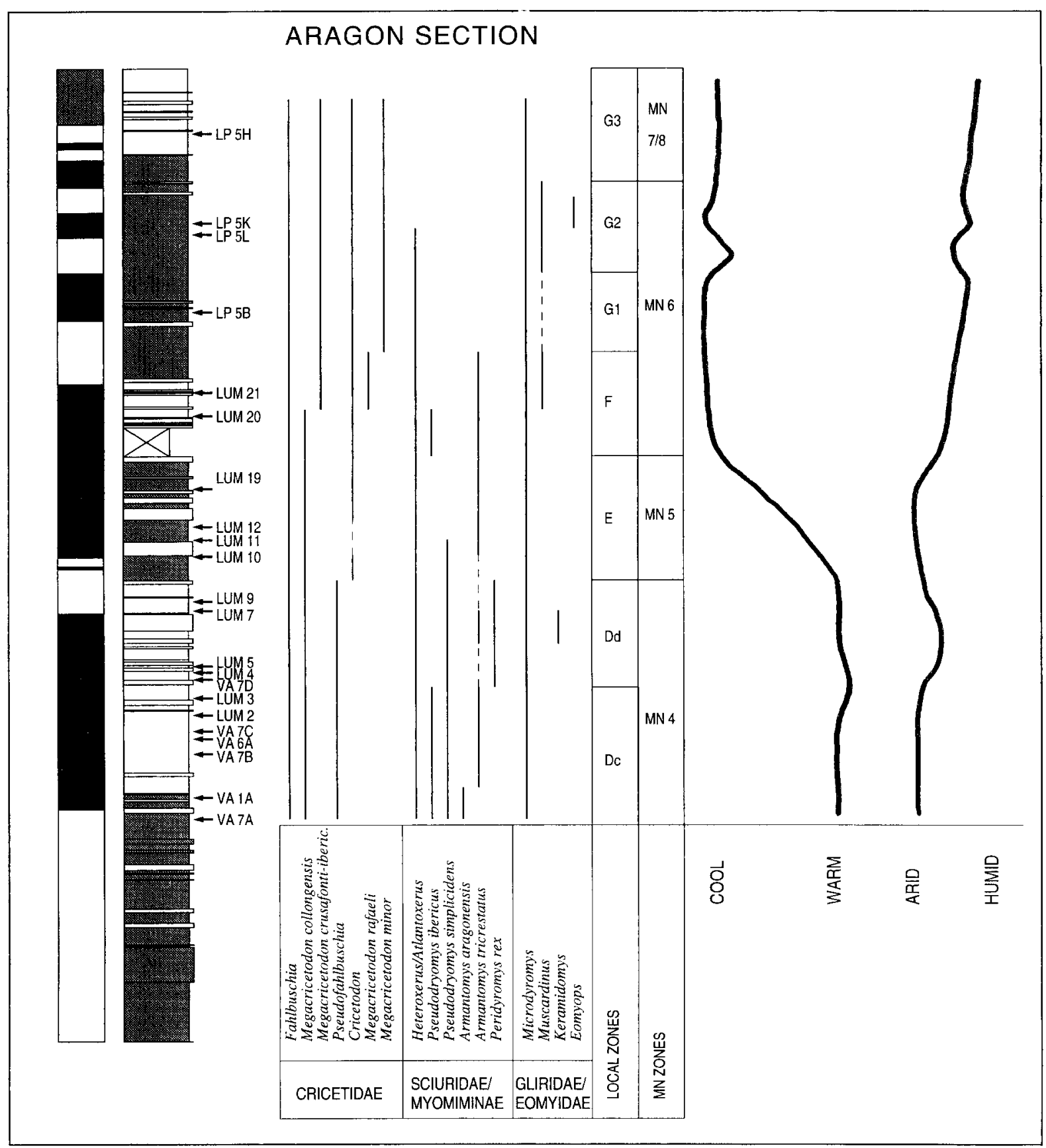

Fig. 7. Biostratigraphy and local biozonations (Dc to G3) of the Aragon section [1] and corresponding MN zones [10]. For the magnetostratigraphy and lithology column see also caption to Fig. 2. Arrows denote fossil localities (VA $=$ Valdemoros; LUM $=$ Las Umbrias; LP = Las Planas). Relative temperature and humidity curves are from Van der Meulen and Daams [1]. 
tion, with the two long normal intervals to the middle part of the Armantes section, corresponding to chrons $\mathrm{C} 5 \mathrm{ACn}$ and $\mathrm{C} 5 \mathrm{ADn}$. The base of the Aragon section occurs in chron C5ADr at 14.8 Ma and the top in chron C5An.2r at approximately $12.5 \mathrm{Ma}$. The lowermost polarity zone of the Aragon section seems to be relatively long, but a higher sedimentation rate is in agreement with the presence of many conglomerate beds.

Seeing as the Armantes section is now well dated reliable time constraints can be applied to the sedimentary sequence. The regular rhythmic alternation of red silts and white limestones suggests that the general depositional setting of the Armantes section in the middle Miocene has faithfully recorded climatic changes in the sedimentary patterns. The distinctly cyclic middle part of the section (54-235 m) contains 27 cycles and covers approximately $3 \mathrm{Myr}$. The resulting average periodicity of $111 \mathrm{kyr}$ suggests that these sedimentary cycles are related to the $\sim 100 \mathrm{kyr}$ eccentricity cycle of Earth's orbit.

\section{Ages of the main biostratigraphic zone bound- aries}

Four Neogene Mammal (MN 4, 5, 6 and 7-8) zones are recognised in the biostratigraphic record of the Aragonian type section (Fig. 7). Our present correlation of the Aragonian polarity sequence to CK94 provides accurate age determinations for the boundaries of these successive MN Zones (Table 1). The important MN 4/MN 5 boundary represents a major climate change [1] and occurs in chron $\mathrm{C} 5 \mathrm{ACr}$ with an age of 14.1 Ma. The MN 5/MN 6 boundary occurs in chron C5ACn (13.8-13.9 Ma) and the MN 6/MN 7-8 boundary occurs in the interval C5Ar.1n-C5Ar.3r $(12.7-13.0 \mathrm{Ma})$. These ages differ significantly from the ages in the most recent continental biostratigraphic timescale [5] and they have important implications for biostratigraphic correlations.

\subsection{Lower Aragonian: $M N 4$}

The MN 3/MN 4 boundary is recognised by the FO of Democricetodon, which is assumed to be more or less contemporanous with the entry of the mastodonts into Europe [9,29]. The age of the MN 3/MN 4 (Ramblian/Aragonian) boundary is still ambiguous [1,5]. For the $\mathrm{MN} 4 / \mathrm{MN} 5$ boundary an accurate age of $14.1 \mathrm{Ma}$ is now found (Table 1). This is in great contrast with Steininger et al. [5], who place this boundary at 17.0 Ma based on indirect correlations with marine biostratigraphy. Our results indicate a significantly longer duration for the MN 4 zone (by approximately $3 \mathrm{Myr}$, which is equivalent to ca. $350 \%$ longer). Moreover, a longer duration for MN 4 much better explains the many important changes in the continental faunal record during the early Aragonian. In the Aragonian type area MN 4 is subdivided into six local zones, significantly more than MN 5 (one), MN 6 (three) and MN 7-8 (one) [1].

In the Aragon section only two local zones (Dc and Dd) are present, which correspond to MN 4. The Dc/Dd boundary occurs in chron C5ADn and has an age of 14.3 Ma. Additional information on the other local zones is provided by the Armantes section where the locality Armantes 1 (= zone $\mathrm{Db}$ ) is magnetostratigraphically dated at 16.0 Ma. The large difference in age between $\mathrm{Db}$ and Dc of $1.2 \mathrm{Myr}$ agrees with the rather drastic change in fauna between $\mathrm{Db}$ and $\mathrm{Dc}$ and indicates that the time interval between 16.0 and 14.8 $\mathrm{Ma}$ is not represented in the fossil record.

Table 1

Positions (or ranges) of MN and local zone boundaries and their ages with respect to the GPTS [2]. Asterisks represent ages from the literature $(*[1] ; * *$ [5]). Decimal fraction denotes position within a (sub)chron as taken from the younger end

\begin{tabular}{|c|c|c|c|}
\hline \multicolumn{2}{|c|}{ BOUNDARY } & CHRON & AGE in Ma \\
\hline MN zones & Local zones & (CK94) & (CK94) \\
\hline \hline MN 7-8/MN9 & G3/H & - & $11.5^{* *}$ \\
MN 6/MN 7-8 & G2/G3 & C5An.1n-C5Ar.3r & $12.7-13.0$ \\
& Gl/G2 & C5AAr-C5ABn & $13.1-13.5$ \\
& F/G1 & C5ABr & $13.5-13.7$ \\
MN 5/MN6 & E/F & C5ACn (0.2-0.6) & $13.8-13.9$ \\
MN 4/MN5 & Dd/E & C5ACr (0.4) & 14.1 \\
& DC/Dd & C5ADn (0.3) & 14.3 \\
MN 3/MN 4 & A/B & - & $17.8^{* *}-18.5^{*}$ \\
\hline
\end{tabular}




\subsection{Middle Miocene climate change: MN 5}

The principal component analyses on the faunal record of the Aragonian type area have been interpreted using individual rodent taxa as environmental indicators [1]. The result is an important cooling event during zone E (MN 5). This cooling phase is assumed to have taken place on the basis of decreasing proportions of Fahlbuschia, which is considered to represent high temperatures. In Zone F, Fahlbuschia has dropped to very low percentages, representing the lowest temperatures (Fig. 7)

The onset of this cooling event can thus be dated as occurring in chron $\mathrm{C} 5 \mathrm{ACr}$, at $14.1 \mathrm{Ma}$, corresponding to the lower boundary of MN 5 . The MN 5/MN 6 boundary is dated in chron C5ACn at $13.8-13.9 \mathrm{Ma}$, which indicates that the cooling event has a duration of approximately 300 kyr. The age of $14.1 \mathrm{Ma}$ is identical to the most recent datings of the climatic changes (cooling) in the paleoceanographic record: Flower and Kennett [3] showed that the major increase in $\delta^{18} \mathrm{O}$ in foraminiferal tests, related to major ice sheet growth on Antarctica, occurred between 14.1 and 14.05 Ma. We conclude that a major cooling event took place in the middle Miocene at 14.1 $\mathrm{Ma}$, both in the marine and the continental environment, thus indicating the global importance of this event.

\subsection{Upper Aragonian: $M N 6$}

Hitherto there has been no accurate dating of the MN 5/MN 6 boundary, which has been placed somewhere between 16 and $15 \mathrm{Ma}$ [5]. The MN $5 / \mathrm{MN} 6$ boundary is by definition the Orleanian/Astaracian and also the local Aragonian $\mathrm{E} / \mathrm{F}$ boundary. MN 6 comprises three local zones (F, G1 and G2), which are well defined in the Aragon type section. Our correlation results in a position for the MN 5/MN 6 boundary in chron $\mathrm{C} 5 \mathrm{ACn}$ at 13.8-13.9 Ma (Table 1). Furthermore, the local zone boundaries $F / G 1$ and $\mathrm{G} 1 / \mathrm{G} 2$ are found in chron $\mathrm{C} 5 \mathrm{ABr}(13.5-13.7)$ and in the interval C5AAr-C5ABn (13.1-13.5 Ma).

The paleomagnetic results from the uppermost part of the Aragon as well as the Armantes section are less reliable and zones can either not be defined or are defined by only a few, or even just one, sample level(s) (Figs. 2 and 3). The MN $6 / \mathrm{MN} 7-8$ boundary was previously positioned at 13.8 Ma [5]. Our results from the Aragon section show that this boundary occurs somewhere in the interval C5Ar.1n-C5Ar.3r (12.7-13.0 Ma). Since there is no clear evidence that the Vallesian has been reached, we are restricted to using the somewhat controversial age of $11.5 \mathrm{Ma}$ for the MN 7-8/MN 9 and hence the Aragonian/Vallesian boundary, based on the possibly diachronous FA of Hipparion [5,12].

\section{Conclusions}

We have established detailed magnetostratigraphic records for two mammal-bearing continental sections of middle Miocene age in the type area of the Aragonian Stage. The polarity sequence of the Armantes section, with 25 polarity intervals, allows an unambiguous correlation to the GPTS [2]. Combining the magnetostratigraphy from the time-equivalent Aragon section with its dense biostratigraphic record results in the correlation of three successive Neogene Mammal (MN) Zone boundaries and six local Aragonian zone boundaries to the GPTS.

Our correlations imply that the MN 4/MN 5 boundary occurs in the normal chron $\mathrm{C} 5 \mathrm{ACr}$, resulting in an age of $14.1 \mathrm{Ma}$. Multivariate analyses of the faunal record of the Aragonian indicate that an important climatic change occurred during MN 5 [1]. Hence, the onset of this climatic cooling is dated at $14.1 \mathrm{Ma}$, which is in excellent agreement with the 14.1-14.05 Ma date for the major increase in $\delta^{18} \mathrm{O}$ in the marine record [3]. Van der Meulen and Daams [1] suggest that during MN 5 the climate changed to cooler and in MN 6 to more humid conditions, while the main increase in $\delta^{18} \mathrm{O}$ is considered to be the result of ice sheet growth on Antarctica. These independent observations of a time-equivalent climate change in both marine and continental records confirm the existence of a cooling event of global importance in the middle Miocene. 
The new age for the MN 4/MN 5 boundary is significantly younger than assumed in the previous conventional timescales $[4,5]$ and indicates a much longer duration (by $3 \mathrm{Myr}$ ) for the $\mathrm{MN} 4$ Zone. This is consistent with the many important faunal changes occurring in $\mathrm{MN} \mathrm{4}$, in which six local Aragonian zones are present. Finally, new ages are also derived for the $\mathrm{MN} 5 / \mathrm{MN} 6$ and MN 6/MN 7-8 boundaries (Table 1).

\section{Acknowledgements}

We thank Ton van Hoof, Jan van Dam, Hans Zijderveld and especially François Lévèque for their help in the field. We also thank Mark Dekkers and Hans de Bruijn for useful discussion. In addition, we also gratefully acknowledge the constructive comments of W.A. Berggren and the two anonymous reviewers. This study was supported by The Netherlands Geosciences Foundation (GOA/NWO). The paleontologists gratefully acknowledge financial support from the Commission of the European Communities (JOULE programme (1989-1992) of the DGCYT, project PB92-0013). [RV]

\section{References}

[1] A.M. van der Meulen and R. Daams, Evolution of early-middle Miocene rodent faunas in relation to longterm paleoenvironmental changes, Palaeogeogr., Palaeoclimatol., Palaeoecol. 93, 227-253, 1992.

[2] S.C. Cande and D.V. Kent, Revised calibration of the geomagnetic polarity time scale for the late Cretaceous and Cenozoic, J. Geophys. Res., in press, 1994.

[3] B.P. Flower and J.P. Kennett, Middle Miocene oceanclimate transition: High-resolution oxygen and carbon isotopic records from Deep Sea Drilling Project Site 588A, southwest Pacific, Paleoceanography 8, 811-843, 1993.

[4] W.A. Berggren, D.V. Kent and J.A. Van Couvering, The Neogene, part 2: Neogene geochronology and chronostratigraphy, in: The Chronology of the Geological Record, N.J. Snelling, ed., Geol. Soc. London Spec Publ. 10, 211-260, 1985.

[5] F.F. Steininger, R.L. Bernor and V. Fahlbusch, European Neogene marine/continental chronologic correlations, in: European Neogene Mammal Chronology, Lindsay et al., eds., pp. 15-46, Plenum, New York, 1990.

[6] V. Fahlbusch, Report on the International Symposium on Mammalian Stratigraphy of the European Tertiary, Newslett. Stratigr. 5(2/3), 160-167, 1976.

[7] R. Daams, M. Freudenthal and M.A. Alvarez, Ramblian: a new stage for continental deposits of Early Miocene age, Geol. Mijnbouw 65, 297-308, 1987.

[8] P. Mein, Resultats du Groupe de travail des Vertebres, in: Report on Activity of R.C.M.N.S. Working Group, J. Senes, ed., pp. 78-81, 1975.

[9] P. Mein, Updating of MN zones, in: European Neogene Mammal Chronology, Lindsay et al., eds., pp. 73-90, Plenum, New York, 1990.

[10] H. de Bruijn, R. Daams, G. Daxner-Höck, V. Fahlbusch, L. Ginsburg, P. Mein and J. Morales, Report of the RCMNS working group on fossil mammals, Reisenburg 1990, Newslett. Stratigr. 26, 65-118, 1992.

[11] R. Daams and M. Freudenthal, Synopsis of the DutchSpanish collaboration program in the Aragonian type area, 1975-1986, in: Biostratigraphy and Paleoecology of the Neogene Micromammalian Faunas from the Calatayud-Teruel Basin, M. Freudenthal, ed., Scr. Geol. Spec. Iss. 1, 3-18, 1988.

[12] S. Sen, Hipparion datum and its chronologic evidence in the Mediterranean area, in: European Neogene Mammal Chronology, Lindsay et al., eds., pp. 495-514, Plenum, New York, 1990.

[13] N.M. Johnson, N.D. Opdyke, G.D. Johnson, E.H. Lindsay and R.A.K. Tahirkheli, Magnetic polarity stratigraphy and ages of Siwalik Group rocks of the Potwar Plateau, Pakistan, Palaeogeogr., Palaeoclimatol., Paleoecol. 37, 17-42, 1982.

[14] K.G. Miller and M.E. Katz, Oligocene to Miocene benthic foraminiferal and abyssal circulation changes in the North Atlantic, Micropaleontology 33, 97-149, 1987.

[15] K. Kurihara and J.P. Kennett, Paleoceanographic significance of Neogene benthic foraminiferal changes in a southwest Pacific bathyal depth transect, Mar. Micropaleontol. 19, 181-199, 1992.

[16] K.G. Miller, M.D. Feigenson, J.D. Wright and B.M. Clement, Miocene isotope reference section, Deep Sea Drilling Project Site 608: An evaluation of isotope and biostratigraphic resolution, Paleoceanography 6, 33-52, $1991 \mathrm{a}$.

[17] N.J. Shackleton and J.P. Kennett, Paleotemperature history of the Cenozoic and initiation of Antarctic glaciation: Oxygen and carbon isotopic analyses in DSDP sites 277, 279, and 281, Init. Rep. DSDP 29, 743-755, 1975.

[18] S.M. Savin, R.G. Douglas and F.G. Stehli, Tertiary marine paleotemperatures, Geol. Soc. Am. Bull. 86, 1499$1510,1975$.

[19] K.G. Miller, J.D. Wright and R.G. Fairbanks, Unlocking the icehouse: Oligocene-Miocene oxygen isotopes, eustacy and margin erosion, J. Geophys. Res. 96, 6829-6848, 1991.

[20] F. Woodruff and S.M. Savin, Mid-Miocene isotope stratigraphy in the deep sea: High-resolution correlations, paleoclimatic cycles and sediment preservation, Paleoceanography 6, 755-806, 1991.

[21] J.D. Wright, K.G. Miller and R.G. Fairbanks, Early and 
middle Miocene stable isotopes: Implications for deep water circulation and climate, Paleoceanography 7, 357389, 1992.

[22] C.E. Barton, Paleomagnetism of sediments collected during leg 90, southwest Pacific, Init. Rep. DSDP 90, 12731316, 1985.

[23] J. Barron, G. Keller and D.A. Duncan, A multiple biochronology for the Miocene, in: The Miocene Ocean: Paleoceanography and Biogeography, J.P. Kennett, ed., Geol. Soc. Am. Mem. 163, 21-36, 1985.

[24] A.A. Dijksman, Geomagnetic reversals as recorded in the Miocene red beds of the Calatayud-Teruel Basin (Central Spain), Ph.D. Thesis, Univ. Utrecht, 1977.

[25] R. Daams, M. Freudenthal and A. Van de Weerd, Aragonian, a new stage for continental deposits of Miocene age, Newslett. Stratigr. 6(1), 42-55, 1977.
[26] H. de Bruijn, Miocene Gliridae, Sciuridae and Eomydae (Rodentia, Mammalia from the Calatayud area, Zaragoza province, Spain) and their bearing on the biostratigraphy, Ph.D. Thesis, Univ. Utrecht, 1965.

[27] T.A.T. Mullender, A.J. Van Velzen and M.J. Dekkers, Continuous drift correction and separate identification of ferrimagnetic and paramagnetic contributions in thermomagnetic runs, Geophys. J. Int. 114, 663-672, 1993.

[28] P.L. McFadden and M.W. McElhinny, The combined analysis of remagnetisation circles and direct observations in paleomagnetism, Earth Planet. Sci. Lett. 87, $161-172,1988$.

[29] C. Bulot, Nouvelle étude des rongeurs et des lagomorphes du Miocéne de Suèvres (Loir-et-Cher), Bull. Mus. Nat1. Hist. Nat., Paris, Ser. 4 10, 385-404, 1988. 